\title{
ONSHORE FORAGING BY AN EARED GREBE
}

JEFFERY T. WILCOX, Sonoma Mountain Ranch Preservation Foundation, 3124 Sonoma Mountain Road, Petaluma, California 94594; jtwilcox@comcast.net

The Eared Grebe (Podiceps nigricollis) is an aquatic, largely halophilic, species that inhabits open waters of the western half of North America (Jehl 1988, Grinnell and Miller 1944). A diving bird, it feeds primarily on benthic invertebrates (Cramp and Simmons 1977, Winkler and Cooper 1986, Jehl 1988, Roberts et al. 2013) but also gleans invertebrates from the water surface (Fjeldså 1981). Eared Grebes breed colonially in large freshwater lakes and marshes throughout the western United States and Canada, but at other life stages are uniquely adapted to use water of high salinity (Boe 1994, Ryser 1985). Immediately after breeding, Eared Grebes migrate to large inland saline lakes with abundant food sources, where they congregate and molt, becoming flightless (Jehl 1988, Ryser 1985, Cogswell 1977). Once the molt has ended and food resources are exhausted (between October and February), large numbers of Eared Grebes depart these inland saline lakes and spend the remaining winter months in open ocean (Jehl 1988). The species overwinters primarily in the Gulf of Mexico (Jehl and McKernan 2002), but coastal waters the entire length of California-including the Channel Islands (Howell 1917) - may host large wintering populations as well (Grinnell and Miller 1944). At Mono Lake, a large saline lake in eastern California, Eared Grebes feed on brine shrimp (Artemia monica) and brine flies (Ephydra hians), the latter often gleaned from the emergent bases of tufa towers (Jehl 1988). Here, I report a previously undescribed terrestrial gleaning behavior on a sandy ocean beach.

In the early afternoon of 14 November 2014, I accompanied a field course from the University of California, Berkeley, to a stretch of beach near Christy Ranch on the west end of Santa Cruz Island, the largest of the Channel Islands, in Santa Barbara County, California. Christy Ranch is situated adjacent to a wide sand beach (approximately 20 meters) that faces $280^{\circ}$ west and extends $1.8 \mathrm{~km}$. While walking north along the beach, I encountered an Eared Grebe hauled out on the wet sand at the maximum extent of the reach of the sweeping surf, just downslope from a deposit of beach wrack - piles of algae, terrestrial plants, driftwood, small rocks, and animal remains that had washed ashore, marking the tideline (Bousfield 1982). Although Merrill (2017) recently reported terrestrial foraging by the Pied-billed Grebe (Podilymbus podiceps) (see below), in 40 years of field experience I had never encountered any grebe species on land, and assumed this one was either injured or in poor health. The grebe appeared unconcerned by my presence during my extensive observations. When I had approached to within 10 meters, I witnessed the grebe lunge and stab in differing directions, seemingly at the sand around it. While I observed, a breaking wave swept slowly up the beach and the grebe rode it back to the surf. In the shallow surf the grebe dove once, briefly, and then bobbed and preened in the surf for a few moments as wave action carried it south, just past me. The grebe then rode back up the sand beach on another breaking wave. When the water retreated, the grebe, now within 5 meters of my position, began lunging and stabbing at the sand again (Figure 1). With the aid of a 200-mm camera lens, I could see that it was foraging for amphipods, specifically beach hoppers (Traskorchestia traskiana).

Amphipods such as $T$. traskiana dwell primarily in or under beach wrack carried ashore by wave action (Bousfield 1982). Beach wrack routinely becomes dislodged with incoming tides or waves that push it higher up the beach (Koch 1989). When the wrack is dislodged, large numbers of $T$. traskiana may be exposed, hopping randomly about until they find their way back to cover. On this occasion, in the moments after the retreat of the wave, I observed the grebe capture many amphipods with little effort. The capture rate diminished over time, yet the grebe persisted in one spot, pivoting on

Western Birds 49:145-148, 2018; doi 10.21199/WB49.2.6 


\section{NOTES}

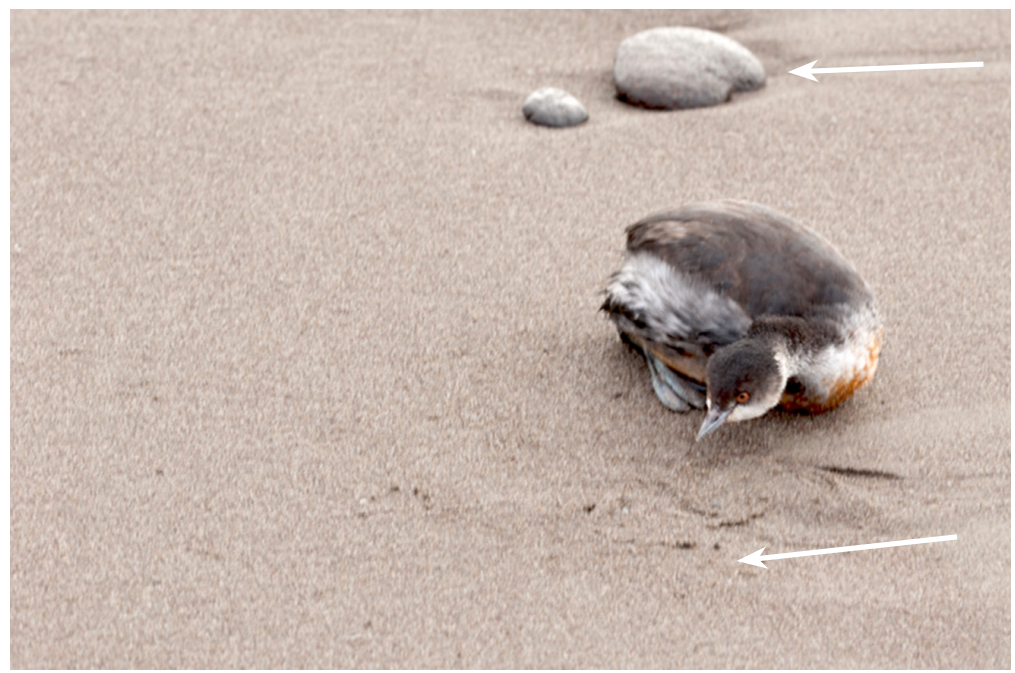

Figure 1. Eared Grebe lunging for amphipods on the open sand beach, downslope from displaced beach wrack (left, not pictured). Christy Ranch, Santa Cruz Island, California. Arrows indicate direction and extent of the last wave sweep (ocean is opposite direction from arrow).

Photo by Jeffery T. Wilcox

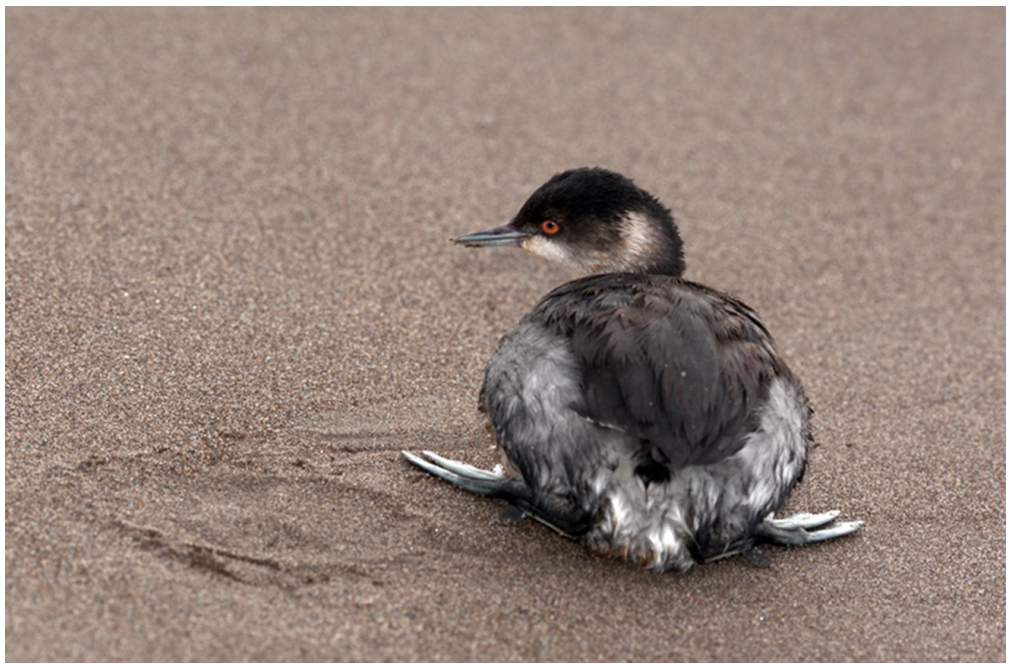

Figure 2. Note depressions in the sand as the Eared Grebe pivots on its breast before pushing off with its feet to lunge for prey. 


\section{NOTES}

its breast and lunging farther and farther (Figure 2). Only once did it clumsily shuffle up the beach after prey, but for only a distance of about twice its body length. When the supply of nearby amphipods was exhausted (i.e., out of reach or out of sight), the grebe caught a wave back into the surf and, using the same wave-riding action as before, repositioned itself on another section of beach and repeated the same feeding behavior as described above. I observed the grebe for more than 30 minutes in total. Even after I had walked to the end of the beach and returned, its behavior continued.

Grebes, as a group, are superb divers but move awkwardly on land because their legs are set far back on their body and the large cnemial crest on the tibiotarsus limits the flexibility of the knee joint, specializations for subsurface diving. Their principal foraging medium is water. Eared Grebes, however, have been known to glean off a terrestrial surface from the safety of water. In a foraging behavior described by Jehl (1988) at Mono Lake, Eared Grebes glean brine flies from tufa towers but do not leave the water to do so, since the towers are surrounded by lake water. In this situation, the grebes are safe from terrestrial predators and can dive under the surface if threatened from above. Merrill (2017) reported observing a Pied-billed Grebe scanning the muddy shore of an artificial pond before jumping from the water to shore and scooting through mud to seize an earthworm. The specific terrestrial foraging behavior that I witnessed on Santa Cruz Island appears to be unique, not only as a new observation for any grebe species, but also because the grebe left the relative safety of the water time and again, repeatedly exposing itself on the open beach.

Foraging behaviors previously described in the Eared Grebe demonstrate its ability to take advantage of congregations of prey (Jehl 1988, Caudell and Conover 2006). The deliberation with which the grebe I observed repeatedly rode the surf to within foraging distance of amphipods exposed by displaced wrack may reflect this, as beach hoppers are concentrated between the edge of breaking waves and the beach wrack. Although the risks of predation are elevated when foraging on the beach, the tradeoff may be access to concentrated prey.

I thank Lyndal Laughrin of the University of California Reserve System, The Nature Conservancy, and Paul Fine and his class IB 157 (Ecosystems of California) at the University of California, Berkeley, for inviting me to join them. Comments from Jeff Alvarez and edits by Nicole Parizeau greatly improved the manuscript.

\section{LITERATURE CITED}

Boe, J. S. 1994. Nest site selection by Eared Grebes in Minnesota. Condor 96:19-35; doi $10.2307 / 1369060$.

Bousfield, E. L. 1982. The amphipod superfamily Talitroidea in the northeastern Pacific region. Family Talitridae. Systematics and distributional ecology. Natl. Mus. Nat. Sci. (Ottawa) Publ. Biol. Oceanogr. 11:1-73.

Caudell, J. N., and Conover, M. H. 2006. Behavioral and physiological responses of Eared Grebes (Podiceps nigricollis) to variations in Brine Shrimp (Artemia franciscana) densities. W. N. Am. Nat. 66(1):12-22; doi 10.3398/15270904(2006)66[12:BAPROE]2.0.CO;2.

Cogswell, H. L. 1977. Water Birds of California. Univ. Calif. Press, Berkeley.

Cramp, S., and Simmons, K. E. L. 1977. Handbook of the Birds of the Middle East and North Africa, vol. 1. Oxford Univ. Press, Oxford, England.

Fjeldså. J. 1981. Comparative ecology of Peruvian grebes-A study of the mechanisms of evolution of ecological isolation. Videnskabelige Meddelelser fra Dansk Naturhist. Forening 143:125-249.

Grinnell, J., and Miller, A. H. 1944. The Distribution of Birds of California. Pac. Coast Avifauna 27.

Howell, A. B. 1917. Birds of the islands off the coast of southern California. Pac. Coast Avifauna 12. 


\section{NOTES}

Jehl, J. R., Jr. 1988. Biology of the Eared Grebe and Wilson's Phalarope in the nonbreeding season: A study of adaptations to saline lakes. Studies Avian Biol. 12.

Jehl, J. R., Jr., and MCKernan, R. L. 2002. Biology and migration of Eared Grebes at the Salton Sea. Hydrobiologia 473:245-253; doi 10.1023/A:1016514725025.

Koch, H. 1989. The effect of tidal inundation on the activity and behavior of the supralittoral talitrid amphipod Traskorchestia traskiana (Stimpson, 1857). Crustaceana 57:295-303; doi 10.1163/156854089X00635.

Merrill, L. 2017. Novel terrestrial foraging behavior in the Pied-billed Grebe (Podilymbus podiceps). Wilson J. Ornithol. 129:416-417.

Roberts, A. J., Conover, M. R., Luft, J., and Neill, J. 2013. Population fluctuations and distribution of staging Eared Grebes (Podiceps nigricollis) in North America. Can. J. Zool. 91:906-913; doi 10.1139/cjz-2013-0181.

Ryser, F. A., Jr. 1985. Birds of the Great Basin: A Natural History. Univ. of Nev. Press, Reno.

Winkler, D. W., and Cooper, S. D. 1986. Ecology of migrant Black-necked Grebes Podiceps nigricollis at Mono Lake, California. Ibis 128:483-491; doi 10.1111/j.1474-919X.1986.tb02700.x.

Accepted 6 January 2018 